\title{
Demographic Changes and Sustainable Demographic Development in the Western Balkans
}

\author{
Verica Janeska $^{1 *}$ | Aleksandra Lozanoska ${ }^{1}$ | Elizabeta Djambaska ${ }^{1}$ \\ ${ }^{1}$ Ss. Cyril and Methodius University in Skopje, Institute of Economics-Skopje, Skopje, Republic of Macedonia
}

\begin{abstract}
The main goal of this paper is to identify the challenges of the sustainable demographic development in terms of the changes and current demographic situation in the Western Balkan countries and to detect the importance of population policies. The analysis is based on the relevant indicators for demographic changes identified in the Sustainable Development Strategy of the EU. The comparative analysis is made for the following countries: Albania, Bosnia and Herzegovina, Croatia, Montenegro, Republic of Macedonia and Serbia. The available data from the Eurostat statistics and other relevant data sources and studies for the last decade are used. The added value of this research is in the comparison of the demographic indicators and recognizing their importance for the sustainable demographic development of this region as one of the key preconditions for the future sustainable development.

The results of the analysis show that the demographic changes are big challenge for the sustainable development in all Western Balkan countries. They have implications in many domains and should be in the focus of the demographers, researchers and policy makers in different fields of the macroeconomics. The lack of data for old-age income adequacy and public finance sustainability imposes the need for comprehensive database in each country as a precondition for continuous monitoring of the demographic changes and for creating appropriate policies regarding the sustainable development. Based on the results of this research, the common areas where the population policies of these countries should be directed are identified.
\end{abstract}

Key words: demographic changes, sustainable demographic development, Western Balkan, employment rate of older workers

JEL Classification: J1, J21, Q01, H5

\section{INTRODUCTION}

The sustainable development means improvement of the quality of life and the welfare of the existing and future generations through making relations between the economic development, protection of the environment and social justice. In these terms the changes in the population development are very important because they have significant influence on all aspects of the sustainable development. In contemporary conditions, worldwide they are manifested in certain misbalance between the working-age population and older population, which has implications on the economic and social development, especially on the social transfers.

Having on mind the importance of the human resources, particularly human capital, as a one of the key factors for sustainable economic development, many studies are observing the

\footnotetext{
*E-mail: verica@ek-inst.ukim.edu.mk
} 
demographic changes and trends. Intensified demographic changes are a global phenomenon resulting from two almost universal trends: declining fertility and increasing life expectancy. Most countries in the world experience declining fertility or have stagnating fertility. In most developed countries fertility is below replacement level, and the majority of countries report increasing life expectancies. As a consequence, most parts of the world will witness demographic aging - defined as a rise in median age of populations and a growing share of people above age 65 - during this 21st century. Large discrepancies, however, will remain (Muenz, 2007). His assumptions, today become real and has happened sooner than expected.

The Western Balkan countries in the last decade are facing major demographic changes, due to low birth rates, changing family structures and intensified emigration abroad. It results with accelerated demographic ageing that implicates serious challenges for the economic and social development and is expected to become even more important in the future. Therefore, the sustainable demographic development is one of the key aspects of the Western Balkan countries' sustainable development.

This paper is considering the demographic changes and the sustainable demographic development in the Western Balkan countries: Albania, Bosnia and Herzegovina, Croatia, Montenegro, Republic of Macedonia and Serbia. The comparative analysis is based on the set of sustainable development indicators agreed upon for monitoring the sustainable development strategy of the European Union (EU SDS). The demographic changes can be followed through one key indicator which refers to the employment rate of the older workers, as well as through several others divided in three groups: Demography (Life expectancy, Population growth, Total Fertility Rate, Migration and Old-age dependency); Old-age income adequacy (Income level of over-65s compared to before); Public finance sustainability (Government debt, Retirement, The impact of aging on public expenditure, Pension expenditure projections).

The analysis refers to the period 2006-2016 and the Eurostat database (and World Bank database for one indicator) as comprehensive source of comparable data is used. Almost all previously mentioned indicators, except: The impact of aging on public expenditure and Pension expenditure projections, for which there isn't any data in the Eurostat and World Bank databases, are analyzed. Although for some of the indicators there isn't data or the data is incomplete for some of the Western Balkan countries, the paper gives certain knowledge for the changes and current conditions regarding the sustainable demographic development in these countries.

\section{OVERVIEW OF THE DEMOGRAPHIC INDICATORS}

\section{Employment rate of older workers}

The employment rate of older workers (55-64 years) is important indicator for the sustainable development because it shows the ageing of the population, the adaptability of the labour force market, the sustainability of the pension and social system. Also, higher employment rate of older workers is guaranteeing strong public finances. The available data for this indicator for the period 2007-2016, despite some oscillations, show that it has a tendency of increase in all Western Balkan countries (Table 1). It is highest in the Republic of Macedonia (almost 12 percentage points) and in Serbia (nearly 11 percentage points), and lowest in Croatia (for 1.5 percentage points). Comparable data ${ }^{1}$ for 2015 shows that the numerical value of this indicator is in the range from 28.2\% (Bosnia and Herzegovina) to 53.6\% (Albania).

Concerning the employment rates of older workers by sex, the differences between the employed men and women were and remain emphasized. Regardless of the more highlighted

\footnotetext{
1 Because for Bosnia and Herzegovina the employment rate of older workers for 2007, 2008, 2009 and 2016 is calculated for the age group 50-64 years, the comparison between the Western Balkan countries is made for 2015 .
} 
dynamics of the women' employment increase, the employment rate of men is significantly higher in all analysed Western Balkan countries. For example, in 2015 the employment rates of older men were in range from 37.3\% (Bosnia and Herzegovina) to $66.9 \%$ (Albania), while of women from $19.8 \%$ to $39.2 \%$ in the same countries (Figure 1 ).

Table 1. Employment rate of older workers (55-64 years) in the Western Balkans, 2007-2016

\begin{tabular}{|l|r|r|r|r|r|r|r|r|r|r|}
\hline & $\mathbf{2 0 0 7}$ & $\mathbf{2 0 0 8}$ & $\mathbf{2 0 0 9}$ & $\mathbf{2 0 1 0}$ & $\mathbf{2 0 1 1}$ & $\mathbf{2 0 1 2}$ & $\mathbf{2 0 1 3}$ & $\mathbf{2 0 1 4}$ & $\mathbf{2 0 1 5}$ & $\mathbf{2 0 1 6}$ \\
\hline Albania & $:$ & $:$ & $:$ & 48.3 & 54.7 & 56.3 & 51.1 & 51.2 & 53.6 & $:$ \\
\hline $\begin{array}{l}\text { Bosnia and } \\
\text { Herzegovina }\end{array}$ & 31.9 & 34.4 & 34.0 & 26.8 & 27.0 & 27.2 & 27.7 & 28.5 & 28.2 & 36.8 \\
\hline Croatia & 36.6 & 37.1 & 39.4 & 39.1 & 38.2 & 37.5 & 37.8 & 36.2 & 39.2 & 38.1 \\
\hline Montenegro & 37.7 & 34.2 & 35.6 & 35.6 & 34.1 & 37.0 & 38.7 & 39.3 & 40.0 & 41.2 \\
\hline $\begin{array}{l}\text { Republic of } \\
\text { Macedonia }\end{array}$ & 28.8 & 31.7 & 34.6 & 34.2 & 35.4 & 35.4 & 37.9 & 38.6 & 40.1 & 40.7 \\
\hline Serbia & 33.5 & 40.6 & 39.3 & 32.9 & 31.4 & 31.6 & 34.3 & 36.7 & 37.3 & 44.2 \\
\hline
\end{tabular}

* The employment rate for 2007, 2008, 2009 and 2016 are for the age group 50-64 years

Source: Eurostat database, Employment rates by sex, age and citizenship (\%), last accessed: 12.4.2018

If we compare this indicator in EU28 with the Western Balkan countries, the situation was and remains unfavourable for the second ones. In 2015, the employment rate of the older workers is $53.3 \%$ (for men $60.1 \%$, while for women $46.9 \%$ ). In the observed period the increase of the employment rates of older women in EU28 is also more emphasized and significantly higher than in Western Balkan countries.

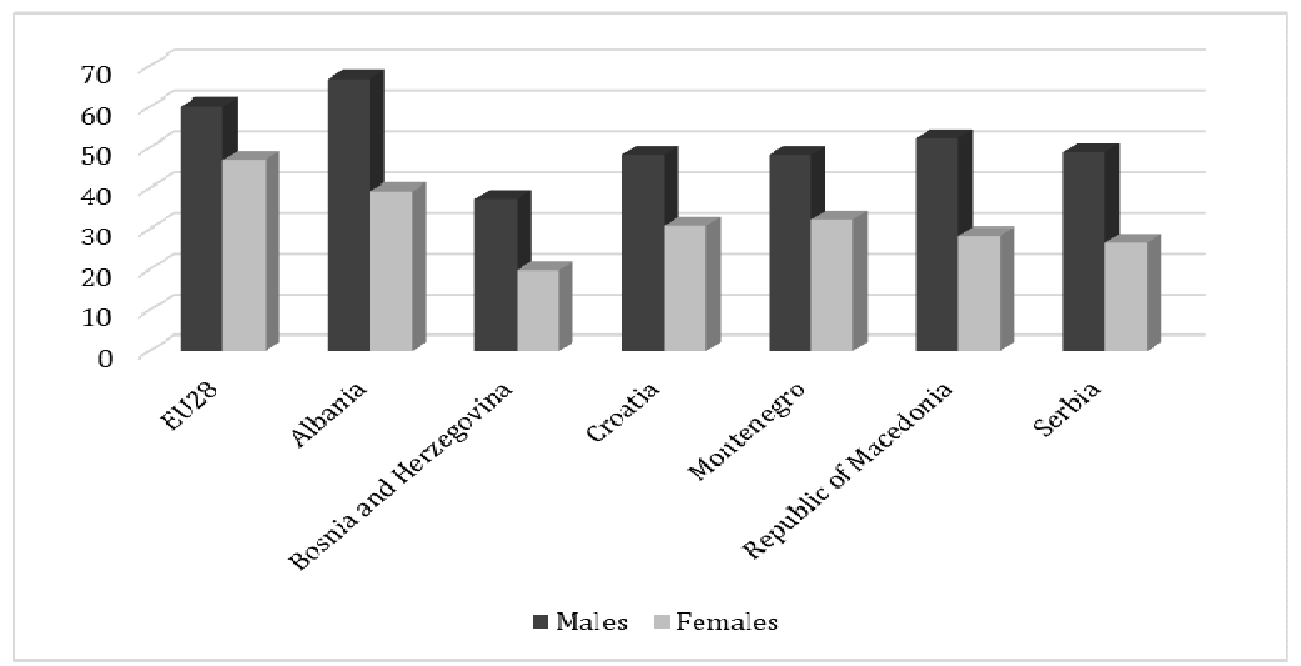

Figure 1. Employment rate of older workers (55-64 years) in the Western Balkans and EU28, by sex, 2015

\section{Source: Eurostat database, Employment rates by sex, age and citizenship (\%), last accessed: 12.4 .2018}

The lower employment rates of older workers, as well as the discrepancies between Western Balkan countries are result of a several factors, such as: the different employment sectors, retirement ages, and opportunities for early and partial retirement, retention of older workers, employment policy incentives and incentives to work longer. Furthermore, the sectorial distribution has an impact on the employment rates by providing more or fewer opportunities to find a job or to remain employed. Considering the intensity of the population ageing in each country, the values of this indicator can be assessed as unfavourable in terms of the social transfers' sustainability. 
Until 2011, the employment rate of older workers has been evaluated against the target set out in the Lisbon strategy and the EU SDS, which was to increase the average EU employment rate among older men and women (55 to 64 ) to $50 \%$ by 2010 . Based on the available data, on EU level the target is met, while none of the Western Balkan countries (except Albania), until 2016 didn't reach that goal.

In the publication titled: Employment and Social Developments in Europe 2012 (European Commission, Directorate-General for Employment, Social Affairs and Inclusion Directorate A, 2012 ) is stated that increasing the employment rates of older workers has become a focus of policy actions because it is considered a promising answer to the demographic challenge of structural longevity. A longer working life can both support the sustainability and adequacy of pensions, as well as bring growth and general welfare gains to an economy. With employment rate of older workers of $55.2 \%$, EU is concerned and aware of the importance to increase it. The Western Balkan countries with lower values of this indicator and intensified demographic ageing have to pay more attention to increase the employment of older workers in order to expect sustainability of the pension systems as one of the key aspects of sustainable development.

\section{Demography}

\section{Life expectancy}

The increase of the life expectancy implicates greater and longer demand for pensions, health care and social protections, as well as long term care for the elderly. In terms of identifying the influence of the life expectancy on the sustainable development of a country, it is important to perceive the life expectancy and the healthy life years at age 65 in which one person is capable to have a good and quality life. However, due to the lack of complete and comparable data for the analysed Western Balkan countries, this analysis refers only to the life expectancy at age 65 . Therefore, one should have in mind that we are observing the expected years of life, but without knowing how long the people will be in good and healthy condition.

The available data on this indicator are from the Eurostat database and is referring to the period 2006-2016 for Croatia, Montenegro, Republic of Macedonia, Serbia and Albania for 20142016 (there is no data for Bosnia and Herzegovina). The expected number of years left to live at age 65 for the total population at this age, in the period 2006-2016 has a tendency of slow, but constant increase in four out of the five analysed countries. It amounts as follows: in Serbia for 1.4 years, in Croatia 1.3, in Montenegro for 1.0 and in the Republic of Macedonia for 0.9 years. Albania in 2016 is characterized with a nearly the same life expectancy at age 65 as it was in 2014 (Table 2).

Having on mind the differences between men and women regarding their health, physical and psychical conditions, it is important to identify the life expectancy at age 65 by sex. This indicator, for men, as well as for women has continuous increase, although, the expected number of years left to live is higher for women. The gap between men and women's life expectancy in 2016 remains around 3.6 years in Croatia, 2.7 in Montenegro, 2.5 in Serbia, 2.0 in Republic of Macedonia and 1.5 years in Albania. When it comes to the life expectancy of men, in 2016 Albania is distinguished with the highest (16.8 years), while Macedonia with the lowest life expectancy at age 65 (14.5 years). As for the women, Croatia has the highest (19.2 years) and Macedonia, again, has the lowest value of this indicator (16.5 years).

In 2016 the life expectancy at age 65 in EU28 amounts 20.0 years for the total population, 18.2 for men and 21.6 years for women. Life expectancies in the Balkan countries (Albania, Montenegro, Republic of Macedonia and Serbia) are comparable to the life expectancies in the lowest ranked EU member states. 
Table 2. Life expectancy at age 65, by sex, in the Western Balkan countries, 2006-2016

\begin{tabular}{|c|c|c|c|c|c|c|c|c|c|c|c|}
\hline & 2006 & 2007 & 2008 & 2009 & 2010 & 2011 & 2012 & 2013 & 2014 & 2015 & 2016 \\
\hline \multicolumn{12}{|c|}{ Total } \\
\hline Albania & $:$ & $:$ & $:$ & $:$ & $:$ & $:$ & $:$ & $:$ & 17.6 & 17.0 & 17.5 \\
\hline $\begin{array}{l}\text { Bosnia and } \\
\text { Herzegovina }\end{array}$ & $:$ & $:$ & $:$ & $:$ & $:$ & $:$ & $:$ & $:$ & : & $:$ & : \\
\hline Croatia & 16.3 & 16.1 & 16.4 & 16.5 & 16.7 & 17.0 & 17.0 & 17.4 & 17.5 & 17.1 & 17.6 \\
\hline Montenegro & 15.1 & 15.2 & 15.7 & 15.7 & 16.3 & 16.2 & 16.2 & 16.3 & 16.4 & 16.2 & 16.1 \\
\hline $\begin{array}{l}\text { Republic of } \\
\text { Macedonia }\end{array}$ & 14.6 & 14.3 & 14.6 & 14.9 & 15.0 & 15.0 & 14.9 & 15.5 & 15.4 & 15.3 & 15.5 \\
\hline Serbia & 14.6 & 14.8 & 15.0 & 15.0 & 15.2 & 15.2 & 15.4 & 15.7 & 15.8 & 15.7 & 16.0 \\
\hline \multicolumn{12}{|c|}{ Males } \\
\hline Albania & $:$ & : & $:$ & : & : & $:$ & $:$ & $:$ & 16.6 & 16.2 & 16.8 \\
\hline $\begin{array}{l}\text { Bosnia and } \\
\text { Herzegovina }\end{array}$ & : & : & : & : & : & : & : & : & : & : & : \\
\hline Croatia & 14.2 & 14.1 & 14.4 & 14.5 & 14.7 & 15.1 & 15.0 & 15.3 & 15.5 & 15.2 & 15.6 \\
\hline Montenegro & 14.0 & 14.1 & 14.5 & 14.7 & 15.2 & 14.9 & 15.1 & 15.0 & 15.1 & 15.0 & 14.6 \\
\hline $\begin{array}{l}\text { Republic of } \\
\text { Macedonia }\end{array}$ & 13.6 & 13.3 & 13.6 & 13.9 & 13.9 & 14.0 & 13.9 & 14.4 & 14.5 & 14.3 & 14.5 \\
\hline Serbia & 13.5 & 13.6 & 13.8 & 13.8 & 14.0 & 13.9 & 14.0 & 14.3 & 14.4 & 14.4 & 14.6 \\
\hline \multicolumn{12}{|c|}{ Females } \\
\hline Albania & $:$ & $:$ & $:$ & $:$ & $:$ & $:$ & $:$ & $:$ & 18.5 & 17.8 & 18.3 \\
\hline $\begin{array}{l}\text { Bosnia and } \\
\text { Herzegovina }\end{array}$ & : & : & : & : & : & : & : & : & : & : & : \\
\hline Croatia & 17.8 & 17.8 & 18.0 & 18.0 & 18.2 & 18.6 & 18.7 & 19.1 & 19.1 & 18.7 & 19.2 \\
\hline Montenegro & 16.0 & 16.0 & 16.7 & 16.7 & 17.3 & 17.4 & 17.2 & 17.5 & 17.5 & 17.2 & 17.3 \\
\hline $\begin{array}{l}\text { Republic of } \\
\text { Macedonia }\end{array}$ & 15.5 & 15.2 & 15.6 & 15.8 & 16.0 & 15.9 & 15.9 & 16.4 & 16.2 & 16.2 & 16.5 \\
\hline Serbia & 15.6 & 15.8 & 16.0 & 16.0 & 16.2 & 16.3 & 16.5 & 16.9 & 16.9 & 16.8 & 17.1 \\
\hline
\end{tabular}

Source: Eurostat database, Life expectancy by age and sex], last accessed: 12.4.2018

The population ageing process and longer life expectancies at age 65 in almost all analysed Western Balkan countries, may lead to higher public spending on older people. However, elderly people are not just recipients of pensions or long-term health care, rather the public health-care costs for older people depend on their health status. Because elderly people are often the ones who provide care for other elderly people, improvements in their health status may mean they are able to provide more care to others (for example, to a spouse or a parent). Furthermore, elderly people often engage in volunteer work or help look after grandchildren, thus providing important services to society that would otherwise have to be purchased in the marketplace (Doyle, McKee, Rechel, Grundy, 2009).

\section{Population growth}

One of the indicators important for the sustainable demographic development is the population growth, measured through the crude rate of total population change. The data in Table 3 shows that in the last decade Western Balkan countries were faced with unfavourable changes, because majority of them noticed certain population decrease. Concerning these data, we should have on mind that maybe they aren't reflecting the real situation due to the intensified emigration abroad in all these countries and lack of relevant data for its scope.

In this terms, striking is the example of Republic of Macedonia, which according this data have a positive population growth, but in the population estimations the real scope of the emigration abroad is not considered. The available Eurostat data shows that in the last decade only in the EU receiving countries the number of Macedonian citizens is increased for about 140.000 
persons. Also, significant is their rise in overseas and other receiving countries all over the world. So, there isn't any doubt that in the analysed period the Republic of Macedonia has faced negative population growth rates.

Considering the available data for the crude rates of total population change for the Western Balkan countries, one can conclude that Croatia is distinguished with very unfavourable change due to the most intensive total population decrease (Table 3). In the observed period the value of the crude rate of total population change is in range from $0.2 \%$ (2006) to $-8.7 \%$ (2016). Similar is the situation in Serbia where the value of this indicator is also negative, but the decrease has constant and significant intensity (from $-3.8 \%$ to $-5.1 \%$, respectively). In Bosnia and Herzegovina, the changes in the population growth are negative since 2010, but less intensified and in 2016 the crude rate of total population change amounts $-1.8 \%$. For Albania there is a lack of data for some of the years, but in the period 2013-2015 it is also faced with the decrease of the total population.

Table 3. Crude rate of total population change in the Western Balkan countries, 2008-2016

\begin{tabular}{|l|r|r|r|r|r|r|r|r|r|r|r|}
\hline & $\mathbf{2 0 0 6}$ & $\mathbf{2 0 0 7}$ & $\mathbf{2 0 0 8}$ & $\mathbf{2 0 0 9}$ & $\mathbf{2 0 1 0}$ & $\mathbf{2 0 1 1}$ & $\mathbf{2 0 1 2}$ & $\mathbf{2 0 1 3}$ & $\mathbf{2 0 1 4}$ & $\mathbf{2 0 1 5}$ & $\mathbf{2 0 1 6}$ \\
\hline Albania & 1.1 & 5.5 & 4.6 & $:$ & $:$ & $:$ & $:$ & -1.0 & -1.3 & -2.2 & -3.3 \\
\hline $\begin{array}{l}\text { Bosnia and } \\
\text { Herzegovina }\end{array}$ & 0.4 & 0.0 & 0.0 & 0.0 & -0.3 & -1.0 & -0.9 & -1.2 & -1.5 & $:$ & -1.8 \\
\hline Croatia & 0.2 & -0.4 & -0.5 & -1.6 & -3.0 & -3.2 & -3.2 & -3.6 & -5.1 & -8.2 & -8.7 \\
\hline Montenegro & 2.5 & 1.5 & 2.6 & 4.4 & 1.4 & 0.7 & 0.9 & 1.0 & 0.9 & 0.2 & 0.3 \\
\hline $\begin{array}{l}\text { Republic of } \\
\text { Macedonia }\end{array}$ & 1.7 & 1.6 & 1.7 & 2.0 & 2.2 & 1.2 & 1.2 & 1.7 & 1.6 & 1.0 & 1.2 \\
\hline Serbia & -3.8 & -4.4 & -4.2 & -3.9 & -4.2 & -4.8 & -4.9 & -4.8 & -4.5 & -5.4 & -5.1 \\
\hline
\end{tabular}

Source: Eurostat database, http://appsso.eurostat.ec.europa.eu/nui/submitViewTableAction.do, last accessed: 24.4.2018

The crude rate of total population change in EU28 despite the oscillations has positive values. The population growth is mainly driven by positive net migration (indicating that immigration is exceeding emigration). Since the demographic ageing is accelerating, and under the assumption that fertility will rise but still will remain at a relatively low level, negative natural change (more deaths than live births) would be inevitable in the future. Therefore, positive net migration is expected to be only factor contributing to long-term population growth in EU28.

Quite opposite is the situation in the Western Balkan countries which are faced with an intensified emigration abroad of young population, which is narrowing the population reproductive base, which implies significantly decreased or negative natural population increase. At the same time, they are challenged with accelerated demographic ageing. So, in near future these countries will face even higher negative crude rates of total population change and very unfavourable demographic situation.

\section{Total fertility rate}

The total fertility rate (TFR) is an indicator which shows whether there is a simple reproduction of the population in a country. When the TFR is smaller than 2.1, once all other conditions are unchanged, there is an assumption that the total and working-age population are decreasing.

According the available data from Eurostat, the Western Balkan countries are facing with below-replacement fertility, despite the manifested oscillations of the TFR indicator values (Table 4). So, there are small changes in the TFR values in the period 2006-2016 and in the position of the separate Western Balkan countries. In 2006 the numerical values of this indicator are in range from 1.38 (Albania) to 1.73 (Montenegro), while in 2016 from 1.42 (Croatia) to 1.79 
(Montenegro). Although with below-replacement fertility Montenegro is separated with relatively better position among Western Balkan countries.

The EU28 is also characterized with below replacement fertility, although in the analysed period the value of TFR is increasing (from 1.54 in 2006 to 1.60 in 2016) and is slightly better compared to majority of the Western Balkan countries (European Commission and Eurostat, 2011). These changes in the TFR, more or less, are result of the changes in the family structures, influenced by fewer marriages, more divorces and increasing share of children born outside marriage. The possibility of a flexible and less traditional family life seems to have a positive impact on individual child-bearing decisions. Also, fertility tends to rise when the welfare of the country is increasing.

Table 4. Total fertility rate in the Western Balkan countries, 2006-2016

\begin{tabular}{|l|r|r|r|r|r|r|r|r|r|r|r|}
\hline & $\mathbf{2 0 0 6}$ & $\mathbf{2 0 0 7}$ & $\mathbf{2 0 0 8}$ & $\mathbf{2 0 0 9}$ & $\mathbf{2 0 1 0}$ & $\mathbf{2 0 1 1}$ & $\mathbf{2 0 1 2}$ & $\mathbf{2 0 1 3}$ & $\mathbf{2 0 1 4}$ & $\mathbf{2 0 1 5}$ & $\mathbf{2 0 1 6}$ \\
\hline Albania & 1.38 & $:$ & $:$ & $:$ & $:$ & $:$ & $:$ & $:$ & 1.79 & 1.67 & 1.56 \\
\hline $\begin{array}{l}\text { Bosnia and } \\
\text { Herzegovina }\end{array}$ & $:$ & $:$ & $:$ & $:$ & $:$ & 1.27 & 1.24 & 1.25 & 1.26 & 1.31 & 1.33 \\
\hline Croatia & 1.47 & 1.48 & 1.55 & 1.58 & 1.55 & 1.48 & 1.51 & 1.46 & 1.46 & 1.40 & 1.42 \\
\hline Montenegro & 1.73 & 1.80 & 1.89 & 1.98 & 1.70 & 1.65 & 1.72 & 1.73 & 1.75 & 1.74 & 1.79 \\
\hline $\begin{array}{l}\text { Republic of } \\
\text { Macedonia }\end{array}$ & 1.46 & 1.46 & 1.47 & 1.52 & 1.56 & 1.46 & 1.51 & 1.49 & 1.52 & 1.50 & 1.50 \\
\hline Serbia & 1.43 & 1.38 & 1.40 & 1.44 & 1.40 & 1.40 & 1.45 & 1.43 & 1.46 & 1.46 & 1.46 \\
\hline
\end{tabular}

Source: Eusrostat database,

http://ec.europa.eu/eurostat/tgm/table.do?tab=table\&init=1\&language=en\&pcode=tps00199\&plugin=1, last accessed: 12.4 .2018

*Source for Bosnia and Herzegovina for 2011-2014 http://mecometer.com/whats/bosnia-andherzegovina/total-fertility-rate/, for 2015-2016: http://www.worldometers.info/world-population/bosniaand-herzegovina-population/

The changes in the total fertility rates in the Western Balkan countries are accompanied by a significant change in the fertility features and determinants. The majority of life births in the Western Balkan countries were within wedlock. It means that, mainly, fertility decline in the last decades was under the influence of marriages and divorce changes (fewer marriages and more divorces). Although, an increase in the number of life births outside marriage is a common feature of the Western Balkan countries (except Bosnia and Herzegovina), its share in the total live births is considerably lower than in EU28 (about 40.0\% in 2015) and have no significant influence on the fertility increase.

Concerning the timing of childbearing in Western Balkan countries evident is the postponement of the first births. Changes of the mean age of childbearing are relatively small or insignificant, while mean age of women at the birth of the first child indicates significant increase in all observed countries. Regarding this indicators, the panel regression results show that mean age of women at the birth of a first child have statistically a significant impact on the TFR for all Western Balkan countries (Janeska, Lozanoska, 2017).

\section{Migration}

In analysing the migration in terms of the sustainable development, the crude rate of net migration plus adjustment should be calculated. The available Eurostat data for the Western Balkan countries show that the value of this indicator has been fluctuating over time. So, in three out of six countries it has a negative value over the whole analysed period (2006-2016). They are: Montenegro, Republic of Macedonia and Albania. It means that the emigration in these countries is higher than immigration. Based on the data from Table 5 in Montenegro the crude 
rate of net migration has raised from -0.1 per 1000 persons (2006) to -1.5 per 1000 persons (2016). In Republic of Macedonia there is a slight decrease of the value of this indicator (from 0.3 to -0.1). The crude rate of net migration has the highest value in Albania, where in the period 2013-2015 (for which there is available data) this indicator has decreased (from -6.3 per 1000 persons to -5.7 per 1000 persons). Croatia is characterized with positive value of the crude rate of net migration until 2009. After this year the indicator started to fall and in 2016 has reached value of -5.4 per 1000 persons. Serbia and Bosnia and Herzegovina are the only two countries that have positive net migration, but in 2016 it was 0.0 per 1000 persons.

Having in mind these changes, it can be noted that majority of the Western Balkan countries have greater emigration than immigration, although not with high scope. But, different studies and data sources show that almost all Western Balkan countries are facing intensive emigration abroad, which imposes doubt about the relevance of the available data, or possibility that countries doesn't have complete registration of the people who are emigrating.

Table 5. Crude rate of net migration plus adjustment in the Western Balkan countries, 20062016

\begin{tabular}{|l|r|r|r|r|r|r|r|r|r|r|r|}
\hline & $\mathbf{2 0 0 6}$ & $\mathbf{2 0 0 7}$ & $\mathbf{2 0 0 8}$ & $\mathbf{2 0 0 9}$ & $\mathbf{2 0 1 0}$ & $\mathbf{2 0 1 1}$ & $\mathbf{2 0 1 2}$ & $\mathbf{2 0 1 3}$ & $\mathbf{2 0 1 4}$ & $\mathbf{2 0 1 5}$ & $\mathbf{2 0 1 6}$ \\
\hline Albania & -4.4 & -0.4 & -1.7 & $:$ & $:$ & $:$ & $:$ & -6.3 & -6.5 & -5.7 & $:$ \\
\hline $\begin{array}{l}\text { Bosnia and } \\
\text { Herzegovina }\end{array}$ & 0.1 & 0.3 & 0.0 & 0.1 & 0.1 & -0.1 & 0.0 & 0.1 & 0.0 & $:$ & 0.0 \\
\hline Croatia & 2.3 & 2.1 & 1.4 & 0.2 & -1.0 & -0.9 & -0.9 & -1.1 & -2.4 & -4.3 & -5.4 \\
\hline Montenegro & -0.1 & -1.5 & -1.5 & 0.0 & -1.5 & -1.5 & -1.5 & -1.5 & -1.5 & -1.5 & -1.5 \\
\hline $\begin{array}{l}\text { Republic of } \\
\text { Macedonia }\end{array}$ & -0.3 & 0.1 & -0.3 & -0.3 & -0.3 & -0.4 & -0.5 & -0.2 & -0.2 & -0.2 & -0.1 \\
\hline Serbia & 0.5 & 0.3 & 0.4 & 0.7 & 0.6 & 0.3 & 0.0 & 0.0 & 0.3 & 0.0 & 0.0 \\
\hline
\end{tabular}

Source: Eurostat database,

http://ec.europa.eu/eurostat/tgm/table.do?tab=table\&init=1\&language=en\&pcode=tps00019\&plugin=1, last accessed: 12.4 .2018

When it comes to the situation in EU28 there is a positive crude rate of net migration, meaning that the number of immigrants is higher than of emigrants, and in 2016 it amounts 3.0\%. Although, the migrant workers have positive influence on the economies of the receiving countries, the analyses are showing that the sustainability of the public finances can't rely on the migrations. Nevertheless, the Strategy of sustainable development of EU recognizes the favourable contribution of the positive net-migration in terms of the challenges imposed by the demographic changes (Janeska, 2012). Migration affects demographic changes in various ways (postponing population decline, have positive influence on the population ageing, since the migrants usually are younger and have higher fertility rates, increasing the labour market supply, solving specific labour market shortages etc.) (European Commission, 2007).

Since the Western Balkan countries are facing intensive emigration abroad, it is obvious that they have the opposite situation concerning the consequences of the migration on the sustainable demographic development. These consequences can be seen in the population growth, natural population increase and population ageing. So, as it was mentioned above, migrations have significant influence on the population growth due to a large proportion of children, young working-age population and population of fertile age lives abroad.

Regarding the consequences to the natural population increase, inevitable is the fact that the share of live births abroad in the total live births is continuously increasing. For illustration, in one research for the Republic of Macedonia, for the purpose of identifying the factors which influence the natural population increase of the migration contingent in Germany, Switzerland and Italy, the correlated component regression is used. The results from the calculations are implying that the share of the Macedonian live births in these three countries in the total 
number of live births in the country, is significantly correlated with the increase of the share of total number of migrants in the total population of the Republic of Macedonia, as well as with the participation of women in these countries in the total women population in the Republic of Macedonia (Janeska, Lozanoska, Djambaska, 2016).

The consequences on the demographic ageing process in the Western Balkan countries are also very concerning. In situation, when the emigration of the young population is significantly intensified, the ageing process in these countries is accelerating. Demographic ageing has numerous implications, and one of them is the increase of the old age dependency ratio.

\section{Old age dependency ratio}

The old age dependency ratio is an indicator of the balance between the older population and the working-age population. It gives information about the potential pressure of the population aging on the public finances. It is determined by the age limit for retirement, by the level at what the pension system depends on the paid contributions or the public financing. The high value the old age dependency ratio implies great burden on the pension system which is based on the paid contributions, especially in terms of lower age limit for retirement. This indicator also gives information about the sustainability of the pension system in terms of the current demographic changes and the expected increase of the public consumption in the future decades.

The available data on the old age dependency ratio in the Western Balkan countries shows that in all of them the value of this indicator is increasing (Table 6). The highest increase is characteristic for Albania, where from 13.1\% (2006) it rose to 18.5\% (2016). Relatively higher increase is noticed in the Republic of Macedonia, from $16.0 \%$ to $18.5 \%$, respectively. In the rest of the analysed countries the increase is around $10 \%$. It is very important to notify that Croatia and Serbia are differentiating from other Western Balkan countries with the highest old age dependency ratio during the whole observed period. It is in range from $26.3 \%$ (2006) to $29.0 \%$ (2016) in Croatia and from 25.1\% (2010) to 28.5\% (2016) in Serbia.

In the EU28 the old-age dependency ratio in the period 2006-2016 is significantly increasing from $25.0 \%$ to $29.3 \%$. Population projections point towards even stronger dependency of older people on persons of working age, as the ratio is expected to increase up to $50 \%$ in 2060 . The trend towards a growing share of older people (aged 65 and over) in the total population and shrinking working-age population (15-64 years) has been observed for a long time. Population ageing is a major driver of the expected increase in pension expenditure in the EU (Eurostat, 2015).

Table 6. Old-age-dependency ratio (per 100 persons) in the Western Balkan countries, 20062016

\begin{tabular}{|l|r|r|r|r|r|r|r|r|r|r|r|}
\hline & $\mathbf{2 0 0 6}$ & $\mathbf{2 0 0 7}$ & $\mathbf{2 0 0 8}$ & $\mathbf{2 0 0 9}$ & $\mathbf{2 0 1 0}$ & $\mathbf{2 0 1 1}$ & $\mathbf{2 0 1 2}$ & $\mathbf{2 0 1 3}$ & $\mathbf{2 0 1 4}$ & $\mathbf{2 0 1 5}$ & $\mathbf{2 0 1 6}$ \\
\hline Albania & 13.1 & 13.3 & $:$ & $:$ & $:$ & $:$ & $:$ & $:$ & 17.5 & 18.0 & 18.5 \\
\hline $\begin{array}{l}\text { Bosnia and } \\
\text { Herzegovina }\end{array}$ & $:$ & $:$ & $:$ & $:$ & $:$ & $:$ & $:$ & $:$ & $:$ & $:$ & $:$ \\
\hline Croatia & 26.3 & 26.5 & 26.7 & 26.8 & 26.7 & 26.5 & 26.7 & 27.1 & 27.6 & 28.3 & 29.0 \\
\hline Montenegro & 19.1 & 19.2 & 19.3 & 19.2 & 19.1 & 18.9 & 19.0 & 19.2 & 19.6 & 20.2 & 20.8 \\
\hline $\begin{array}{l}\text { Republic of } \\
\text { Macedonia }\end{array}$ & 16.0 & 16.0 & 16.2 & 16.3 & 16.4 & 16.5 & 16.6 & 16.9 & 17.5 & 18.0 & 18.5 \\
\hline Serbia & 25.7 & 25.6 & 25.6 & 25.4 & 25.1 & 25.1 & 25.3 & 25.9 & 26.7 & 27.5 & 28.5 \\
\hline
\end{tabular}

Source: Eurostat database,

http://ec.europa.eu/eurostat/tgm/table.do?tab=table\&init=1\&language=en\&pcode=tps00198\&plugin=1, last accessed: 12.4 .2018

The high values, as well as the increase of the old age dependency ratio, in all Western Balkan countries implies heavier burden on the working-age population to provide social expenditure 
to support the ageing population. Therefore, the countries should (if they didn't) undertake reforms to limit the increasing effect of a population ageing on public pension expenditure. These reforms should include cancelation or restriction of the early retirement schemes, increasing the statutory ages or providing incentives to stay in the labour market beyond the legal retirement age on a voluntary basis.

\section{Old-age income adequacy}

The old-age income adequacy measured through the aggregate replacement ratio is gross median individual pension income of the population aged 65-74 relative to gross median individual earnings from work of the population aged 50-59, excluding other social benefits. Considering the available data on this indicator for the Western Balkan countries, i.e. the lack of data for all countries and for the complete analysed period, the comparison is difficult to be made. Therefore, the analysis is focused only on identifying the changes and current situation in the countries for which there is available data.

According the data in Table 7, among the three countries for which there is a comparable data on this indicator, Republic of Macedonia has the highest aggregate replacement ratio, which increased from 55\% (2012) to 72\% (2016). It means that in 2016 the pensioners aged 65-74 had on average incomes equal to $72 \%$ of the average earnings of people close to retirement (aged 50-59). In Serbia the value of this indicator in the period 2013-2016 is around 47\%. For Croatia there is data for longer period (2010-2016) and according it, the aggregate replacement ratio had a continuous increase until 2015 (from $0.32 \%$ to $0.40 \%$ ), In 2016 the pensioners aged 65-74 had on average incomes equal to $39 \%$ of the average earnings of people close to retirement (aged 50-59).

Table 7. Aggregate replacement ratio (in \%) in the Western Balkan countries, 2010-2016

\begin{tabular}{|l|r|r|r|r|r|r|r|}
\hline & $\mathbf{2 0 1 0}$ & $\mathbf{2 0 1 1}$ & $\mathbf{2 0 1 2}$ & $\mathbf{2 0 1 3}$ & $\mathbf{2 0 1 4}$ & $\mathbf{2 0 1 5}$ & $\mathbf{2 0 1 6}$ \\
\hline Albania & $:$ & $:$ & $:$ & $:$ & $:$ & $:$ & $:$ \\
\hline Bosnia and Herzegovina & $:$ & $:$ & $:$ & $:$ & $:$ & $:$ & $:$ \\
\hline Croatia & 0.32 & 0.36 & 0.36 & 0.37 & 0.40 & 0.40 & 0.39 \\
\hline Montenegro & $:$ & $:$ & $:$ & $:$ & $:$ & $:$ & $:$ \\
\hline Republic of Macedonia & $:$ & $:$ & 0.55 & 0.60 & 0.65 & 0.70 & 0.72 \\
\hline Serbia & $:$ & $:$ & $:$ & 0.49 & 0.47 & 0.47 & 0.47 \\
\hline
\end{tabular}

Source: Eurostat database,

http://ec.europa.eu/eurostat/tgm/table.do?tab=table\&init=1\&language=en\&pcode=tespn070\&plugin=1, last accessed: 12.4 .2018

The average income of people aged 65 and over in the EU28 relative to the earnings of people in their 50s has increased by six percentage points in the period 2010-2016. This increase, as well as the increase of the value of this indicator in the Western Balkan countries is a result of the same changes in the demographic structure of the population by age. Given the pressure on pension funds due to the effects of demographic ageing, it is very unlikely that pensions of elderly people would actually increase. The increase in the replacement ratio might rather be a result of decreasing incomes of the working-age population. Besides addressing poverty, pension systems play a role in allowing retirees to maintain adequate living standards comparable with those achieved during their working lives (Eurostat, 2015).

Over the past decade most of the Western Balkan countries have reformed their pension systems to improve their medium and longer term sustainability as a precondition for delivering on adequacy objectives. However, the countries have to face trade-offs and difficult choices when trying to reconcile and optimize sustainability and adequacy concerns. Achieving the goal 
of cost-effective and safe delivery of adequate benefits that are sustainable is quite challenging (European Commission, 2012).

\section{Public finance sustainability}

\section{Government debt}

When it comes to the public finance sustainability in terms of the sustainable demographic development, the government debt as a percentage of GDP is an important indicator to be considered. Based on the available and comparable data for the period 2006-2016 in all Western Balkan countries, the general government gross debt as a percentage of GDP, although with some oscillations, has a tendency of increase (Table 8). The highest increase of 45.5 percentage points is characteristic for Croatia, while the lowest for Macedonia 8.1 percentage points. In the rest of the Western Balkan countries it is as follows: Montenegro for 35.0 percentage points, Serbia for 33.8, Bosnia and Herzegovina for 23.2 and Albania for 14.8 percentage points.

It is very important to point out that there is an EU reference value for the government debt of $60 \%$ of GDP. ${ }^{2}$ Considering the available data on the Western Balkan countries, only in Bosnia and Herzegovina and in the Republic of Macedonia the value of this indicator didn't reach that threshold. In the other countries, although in different year, the reference value of the government debt is exceeded.

The general government gross debt in the EU28 has also increased sharply from $60.1 \%$ in 2006 to $86.7 \%$ in 2014. In 2016 it reached $83.5 \%$. The big changes with this indicator happened after 2009, and were result of the economic crisis. Unfortunately, there have been no signs of recovery since the onset of this crisis. In EU28 the government debt is exceeding the EU reference value starting from 2006 (except in 2007) (Eurostat database, 2018).

Table 8. General government gross debt as a \% of GDP in Western Balkan countries and EU28, 2006-2016

\begin{tabular}{|l|r|r|r|r|r|r|r|r|r|r|r|}
\hline & $\mathbf{2 0 0 6}$ & $\mathbf{2 0 0 7}$ & $\mathbf{2 0 0 8}$ & $\mathbf{2 0 0 9}$ & $\mathbf{2 0 1 0}$ & $\mathbf{2 0 1 1}$ & $\mathbf{2 0 1 2}$ & $\mathbf{2 0 1 3}$ & $\mathbf{2 0 1 4}$ & $\mathbf{2 0 1 5}$ & $\mathbf{2 0 1 6}$ \\
\hline Albania & 56.7 & 53.6 & 55.1 & 59.7 & 57.7 & 59.4 & 62.1 & 70.4 & 72.0 & 73.7 & 71.5 \\
\hline $\begin{array}{l}\text { Bosnia and } \\
\text { Herzegovina }\end{array}$ & 21.2 & 18.7 & 30.9 & 35.1 & 42.8 & 43.1 & 43.4 & 44.5 & 45.0 & 45.4 & 44.4 \\
\hline Croatia & 38.9 & 37.7 & 39.6 & 49.0 & 58.3 & 65.2 & 70.7 & 82.2 & 86.6 & 86.7 & 84.4 \\
\hline Montenegro & 36.3 & 31.0 & 32.1 & 41.4 & 43.7 & 48.6 & 56.9 & 58.7 & 63.4 & 69.3 & 71.3 \\
\hline $\begin{array}{l}\text { Republic of } \\
\text { Macedonia }\end{array}$ & 30.6 & 23.5 & 20.6 & 23.6 & 24.1 & 27.7 & 33.7 & 34.0 & 38.1 & 38.2 & 38.7 \\
\hline Serbia & 40.3 & 33.4 & 32.4 & 36.0 & 43.7 & 46.6 & 57.9 & 61.1 & 71.9 & 76.0 & 74.1 \\
\hline
\end{tabular}

Source: The World Bank Data, https://data.worldbank.org/indicator/GC.DOD.TOTL.GD.ZS?locations=AL, last accessed: 10.4 .2018

The increase of the government debt as a percentage of GDP is a consequence of several factors: revenue shortfalls due to the decline in the economic activity, measures to support the economy, including large-scale interventions to support the financial sector, as well as the effect of negative or very low economic growth (Eurostat, 2015). Recognizing that high levels of government debt are not sustainable in the long-term, the Western Balkan countries should put greater emphasis on reviving their economic growth.

2 The current provisions are defined in the 2012 consolidated version of the Treaty on the Functioning of the European Union (http://eur-lex.europa.eu/legal-content/EN/TXT/?uri=CELEX:12012E/TXT). 
Retirement

Regarding the sustainable demographic development one of the key aspects is the retirement. It can be explained with the duration of working life (in years). In the Eurostat database there are available data on this indicator only for three out of six Western Balkan countries. So, according to this data, the duration of working life is increasing (Table 9). It is highest in Croatia and lowest in the Republic of Macedonia. However, the differences among these three analysed countries aren't very big, since this indicator is between 30-32 years in Croatia and Macedonia, and a little bit lower in Montenegro (28-30 years). When it comes to the duration of working life it is important to see the differences by sex. In the Western Balkan countries, the number of years a person could be expected to be active in the labour market throughout his or her life, in the analysed period, was always higher for men. For illustration, in 2016 in Croatia the duration of working life for men was 33.9 and for women 30.2 years, while for Macedonia 37.2 and 24.4 years, respectively. A slight convergence between the two sexes is visible over time, meaning that the gap is narrowing.

In EU28 the changes in this indicator are relatively similar. It means that the number of years a person could be expected to be active in the labour market is increasing. For example, from 33.8 (2006) to 35.6 years (2016). The duration of working life is higher for men than for women. Also, the differences according this indicator between men and women are tightening, because this number for men has increased from 36.9 (2006) to 38.0 years (2016), while for women from 30.6 to 33.1 years, respectively.

Table 9. Duration of working life (in years) in Western Balkan countries and EU28, 2006-2016

\begin{tabular}{|c|c|c|c|c|c|c|c|c|c|c|c|}
\hline & 2006 & 2007 & 2008 & 2009 & 2010 & 2011 & 2012 & 2013 & 2014 & 2015 & 2016 \\
\hline Albania & : & : & : & : & : & : & : & : & : & : & : \\
\hline $\begin{array}{l}\text { Bosnia and } \\
\text { Herzegovina }\end{array}$ & : & : & : & : & : & : & : & : & : & : & : \\
\hline Croatia & 31.2 & 31.5 & 31.7 & 31.8 & 31.6 & 31.4 & 31.2 & 31.1 & 32.3 & 32.6 & 32.2 \\
\hline Montenegro & & & & & & 27.8 & 28.7 & 28.7 & 30.1 & 30.8 & 31.2 \\
\hline $\begin{array}{l}\text { Republic of } \\
\text { Macedonia }\end{array}$ & 30.0 & 30.2 & 30.6 & 30.9 & 31.1 & 31.1 & 30.9 & 31.3 & 31.3 & 31.2 & 31.0 \\
\hline Serbia & : & : & : & : & : & : & : & : & : & : & \\
\hline
\end{tabular}

Source: Eurostat database, http://appsso.eurostat.ec.europa.eu/nui/show.do?dataset=lfsi_dwl_a\&lang=en, last accessed: 23.4.2018

The world has largely focus attention on the pension system, because of the increasing need to cover pension benefits of socially excluded groups and provide all conditions to enable older population, economic independence and the necessary conditions for living standards. Worldwide, $25 \%$ of the population covered by adequate social protection, and half has no social protection. The level of social protection depends on the level of GDP, employment rates in the relevant sectors of the economy, the share of self-employed in the labor market. In order to overcome the problem of social protection recommended modification of the contribution rate to social security, to be available to many socially disadvantaged, i.e. pension insurance are recommended and structural reforms in the macroeconomic environment in order to create conditions for the functioning of the pension system (Đukić, Balaban, Radisavljević, 2017).

\section{CHALLENGES AND POLICIES OF THE SUSTAINABLE DEMOGRAPHIC DEVELOPMENT}

The small population growth and the intensive demographic aging, which assumes decrease of the working-age population, as well as the increase of the life expectancy, accompanied with low fertility rates, undoubtedly will have unfavourable influence on the economic growth and sustainable demographic development of the Western Balkan countries. It is real to expect that 
these changes will significantly influence the sustainability of the pension systems and the provision of the health and social protection for the older population, on middle and long-term. The need to anticipate these changes is especially emphasized in the terms when they can't be compensated by postponed retirement and labour force immigration, which can jeopardy the sustainable development and the welfare of the population.

The analysis of the available indicators important for the sustainable demographic development gives relevant knowledge for the current conditions and expected changes. In these terms, the main challenges of the sustainable demographic development can be identified. These challenges are as follows. It is necessary to apply more implicit measures of the population policy which can provide higher and sustainable increase of the fertility rates. Also a set of policies and measures directed towards decrease of the emigration abroad of highly educated young population, especially in terms when there is a large number of unemployed with high educational level, should be adopted. It is very important to increase the employment rates, including those of the older workers, which is the key assumption to provide sustainability of the social transfers in the future. No less significant is the restructure of the social protection system, since it is expected the contingent of elderly to be significantly increased.

The demographic changes in the Western Balkan countries in the last decades are being watched in absence of appropriate population policy which can direct them, regardless of the manifested unfavourable changes in the natural and migration movements of the population. The need for comprehensive population policy in the Western Balkan countries was identified in the sixties and seventies of the last century, anticipating the possible consequences of the demographic changes on the economic and social development. Unfortunately, the creators of the population policy didn't recognize the significance of this question, neglecting the long-term consequences and implications of the population development.

The insights in the population policies show that in most of the Balkan countries the "major" concern about population ageing appears earlier than the concern for "too low" fertility. The Western Balkan countries have policies related to fertility: with the purpose to "raise" it, and one (Albania) to "maintain" its level. Only Bosnia and Herzegovina government preferred "no intervention" (UN, World Population Policies Database, 2018)

The current demographic situation indicates delayed fertility policies, measures and activities with relatively small effects on fertility "raise". Experiences show that policies designed to increase fertility have only had limited success. So, the Western Balkan countries should design fertility policies to their specific pathways to low fertility and the social, economic and institutional environment in which fertility behaviour occurs. In circumstances when the importance of the biological factors is declining, they should pay more attention on the socioeconomic determinants of the fertility decrease and its complexity. In this respect recommendations in four areas of intervention are pointed out. Related to pro-natalist policies measures should be more complex and focused on the socio-economic factors that determine childbearing postponement to older ages. Financial incentives should be better targeted and focused on reduction of the opportunity cost of having children. Because marriages are still an important determinant of fertility increase, the Western Balkan countries must pay more attention on family friendly policies with consistent measures and activities. Also, the Western Balkan countries should implement proper policies concerning work-life balance, because the compatibility between childbearing and labour force participation of women is one of the key determinants influencing fertility (Janeska, Lozanoska, 2017).

Ageing will pose a challenge for government finances and social programmes. On the one hand, as the proportion of individuals of working age declines, so will government revenues from employment taxes and the growing number of elderly will need health care. In many advanced economies, pension systems risk bankruptcy. These problems can be tackled by policy reforms, such as changing employment, pension and tax policies. The decline in working-age populations could slow economic growth. Indeed, the Economist Intelligence Unit's economic 
projections for Croatia and Serbia to 2030 take this factor into account, and on this basis predict a decline in the rate of economic growth in these countries (European Environment Agency. 2010).

In the present conditions, when the working-age population is under the continuous pressure to provide the social expenditures for support of the ageing population, it is necessary to take policies and actions for the elderly. This means to provide incentives the elderly to work longer, to increase the retirement age and continuous to develop their skills and lifelong learning. Healthy public finances, reflected by general government gross debt, are essential to meet the needs of ageing populations and to promote economic growth while preventing debt from being handed down to future generations. In addition to pensions, which make up a big part of public expenditure, other expenditure might be needed to provide adequate old-age care and social protection. With an ageing population, the Western Balkan countries are facing trade-offs between pensions that are sustainable, on the one hand, and adequate, on the other. Besides addressing poverty, pension systems play a role in allowing retirees to maintain living standards comparable to those achieved during their working lives, thus preventing social exclusion of the elderly. The shift towards longer working lives (later retirement) in the Western Balkan is essential to support the sustainability and adequacy of pension systems.

\section{CONCLUSION}

The Western Balkan countries are facing major demographic changes, including decreasing of the population growth rate due to the below replacement fertility rates, an ageing population accompanied with increase of the life expectancy at age 65 and old-age dependency ratio, changing family structures and intensified emigration abroad.

Since 1990, Western Balkan countries have lost around a tenth of their populations. They could lose another 14 percent of their current populations by 2050, not least because of emigration, especially of young people. The low fertility rates of around 1.3 children per woman are another contributor to the rapid shrinkage of the populations of the West Balkan states. At the same time, those populations are aging rapidly: while today around 15 percent of inhabitants are at least 65 , this figure will probably rise to 26 percent by mid-century. In future, providing adequately for the growing number of old people is likely to pose a major challenge for the comparatively poor countries of the Western Balkans (Sievert, S. at al. 2017). These changes have imposed serious challenges for the economic, social and sustainable demographic development.

Based on the analysis on the available demographic indicators in terms of the sustainable demographic development, several relevant conclusions can be made. The demographic changes in the Western Balkan countries can be assessed as unfavourable due to the negative changes which are characteristic for the majority of these indicators. Although is characterized with increase, the employment rate of older workers is still relatively low, which imposes the question of the social transfers' sustainability on medium and long term.

The population ageing process and longer life expectancy at age 65 in almost all Western Balkan countries, mean that the public expenditures for pensions and for health and social protection will increase. However, one should consider that although the elderly are recipients of the previously mentioned public spending, significant amount of these costs depends on their health and social status.

According the available data on the population growth seen through the crude rate of total population change, most of the Western Balkan countries are facing negative trend of this indicator, i.e. a decrease. This changes are expected since most of them are facing intensive emigration abroad, especially of young population, which is shrinking the population reproductive base and consequently results in decrease or negative natural population increase. 
That is implicating very concerning demographic situation in the future demographic development of these countries.

The total fertility rate (TFR) although has a tendency of increase, shows that in all Western Balkan countries there isn't a simple reproduction of the population, i.e. that they are facing below replacement fertility. This implicates further decrease of the total population. The most important determinants of low TFR in these countries are the changes in the marriages and divorces, the postponed timing of childbearing, and the mean age of women at the birth of first child which is significantly rising.

Recent studies show that the Western Balkan countries are characterized with significant intensification of the emigration abroad. The emigration abroad implicates large proportion of children, young working-age population and population of fertile age to live abroad. It causes the population growth of the Western Balkan countries to decrease, their natural population increase to be negative and the demographic aging to accelerate.

The shrinking proportion of the working-age population combined with the rising number of retirees puts pressure on public finances. This is reflected by the old-age dependency ratio, which has been continuously increasing over the last decade in all Western Balkan countries. These changes impose heavier problem for the working-age population to provide social expenditures to support the elderly. In these terms, the old-age income adequacy, measured through the aggregate replacement ratio is important indicator for the sustainable demographic development, but moreover for sustainability of the pension systems. The average income of people aged 65 and over relative to the earnings of the people in their 50s has increased in almost all Western Balkan countries. Since, these countries are facing great pressure on their pension systems and it is very unlikely that the pensions will actually increase, it is necessary for the Western Balkan countries to start or to continue reforming their pension systems in order to provide their medium and long term sustainability.

The government debt as a percentage of GDP is increasing in all Western Balkan countries. The available data shows that only in Bosnia and Herzegovina and in the Republic of Macedonia the value of this indicator didn't reach the EU reference value (the government debt of $60 \%$ of GDP), while in the other countries, although in different years, it is exceeded. The high levels of government debt are not sustainable in the long-term, and the Western Balkan countries should put greater emphasis on intensifying their economic growth. But, due to the demographic changes, particularly the intensified emigration abroad, the growth should be achieved in terms of reduced human capital, which is one of the most important factors for economic development of these countries.

All above mentioned demographic changes have more or less significant impact on the sustainable demographic development of the Western Balkan countries. Since, all these countries are facing the increased impact of population aging on the public expenditures and on the pension system sustainability, it is an imperative for them to take consistent and comprehensive population and fertility policies, with particular attention on the emigration abroad. Main challenges of the sustainable demographic development in the Western Balkan countries are the following: application of more implicit measures of the population policy to stimulate the fertility rates increase; decrease of the emigration abroad, especially of the highly educated and young persons; increase of the employment rates, including those of older workers; restructure of the social protection system, particularly for the older population, in context of its expected increase.

Development has been equated with the economic growth for decades, where the increase in the gross national product (GNP) per capita has been an indicator of the increase in the quality of people's life. Although economic growth is certainly a necessary condition for increase in personal well-being, it however does not necessarily correspond with the improvement of people's life conditions. For example, it is noticed that, in some countries, relatively high level of gross national product GNP per capita is not followed by the high quality of life as expressed in 
terms of life expectancy, adult literacy, and infant mortality (Radovanović, 2017). It implies the need for different approach to the demographic issues and more resources for implementation of the demographic policies, considering the importance of the sustainable demographic development for the economic development. Having in mind the current demographic situation in the Western Balkan countries it is even more emphasized.

\section{REFERENCES}

Doyle, Y., McKee, M., Rechel, B., Grundy, E. 2009. "Meeting the challenge of population ageing". BMJ (Clinical research ed.), 339. b3926. ISSN 0959-8138 DOI: 10.1136/bmj.b3926

Đukić, G., Balaban, M., Radisavljević, G. 2017. "The Macroeconomic Framework of the Functioning of Public Compulsory Pension Insurance". Economic Analysis, [S.l.], v. 50, n. 1-2, p. 26-37, oct. 2017. ISSN 2560-3949. Available at: <http://www.library.ien.bg.ac.rs/index.php/ea/article/view/342>. Date accessed: 31 may 2018.

European Commission. Directorate-General for Employment, Social Affairs and Inclusion Directorate A. 2012. "Employment and Social Developments in Europe 2012", Brussels.

European Commission. 2012. "Pension Adequacy in the European Union 2010-2050". Report prepared jointly by the Directorate-General for Employment, Social Affairs and Inclusion of the European Commission and the Social Protection Committee.

European Commission and Eurostat. 2011. "Demography Report 2010 - Older, more numerous and diverse Europeans", Commission Staff Working Document.

European Commission Directorate-General for Employment, Social Affairs and Equal Opportunities Unit E.1. 2007. "Europe's demographic future: Facts and figures on challenges and opportunities". Luxembourg: Office for Official Publications of the European Communities.

European Environment Agency. 2010. "Environmental trends and perspectives in the Western Balkans: future production and consumption patterns. Part 2: Driving forces that shape environmental futures in the Western Balkans". No.1/2010

Eurostat. 2015. "Sustainable Development-demographic changes". http://ec.europa.eu/eurostat/statistics-

explained/index.php/Archive:Sustainable_development_-_demographic_changes, last accessed: 25.4 .2018

Eurostat database. 2018.

http://ec.europa.eu/eurostat/tgm/table.do?tab=table\&init=1\&language=en\&pcode=tsdde41 0\&plugin=1 last accessed: 25.4 .2018

Janeska, V., Lozanoska A. 2017. "Fertility Changes in the Balkan Countries - Main Features and Challenges of the Below-Replacement Fertility". Proceedings from the Fifth International Conference of Balkans demography: The Population of the Balkans at the Dawn of the $21^{\text {st }}$ Century. DemoBalk. Ss. Cyril and Methodius University in Skopje. Institute of Economics Skopje. Skopje. p. 7-30.

Janeska, V., Lozanoska. A., Djambaska. E. 2016. "Demographic Consequences of the Emigration from the Republic of Macedonia". Economic Development. Journal of the Institute of Economics-Skopje. Year. 18 No. 1-2/2016. Skopje. p. 157-178

Janeska, V. 2012. "Demographic changes and sustainable development of the Republic of Macedonia". Proceedings of the Scientific Symposium in Honour of the $100^{\text {th }}$ Birth Anniversary of Academician Kiril Miljovski (1912-1983). Macedonian Academy of Sciences and Arts. Ss. Cyril and Methodius University in Skopje. Faculty of Economics-Skopje. Skopje. p. 171-190 
Muenz, R. 2007. "Aging and Demographic Change in European Societies: Main Trends and Alternative Policy Options". SP Discussion paper No.0703. Hamburg Institute for International Economics. p. 1

Radovanović, Bojana. 2017. "Well-Being - Resources, Happiness and Capabilities: Theoretical Discussions and the Evidence from the Western Balkans". Economic Analysis, [S.l.], v. 46, n. 34 , p. 152-163, oct. 2017. ISSN 2560-3949. Available at: <http://www.library.ien.bg.ac.rs/index.php/ea/article/view/265>. Date accessed: 31 may 2018

Sievert, S. at al. 2017. "Europe's Demographic Future-Where the Regions Are Heading after a Decade of Crises". Berlin Institute for Population and Development. p.138

UN World Population Policies Database. 2018.

http://www.un.org/en/development/desa/population/publications/policy/worldpopulation-policies-2013.shtml last accessed: 28.4.2018

Article history: $\quad$ Received: April 30, 2018

Accepted: June 1, 2018 